\title{
Role and Impact of Media on Younger Generation: A Sociological Approach with Respect to Covid-19 Lockdown
}

\author{
Shatakshi Semwal* and Ragini Ranawat \\ Department of Home Science, University of Rajasthan, Jaipur, India \\ *Corresponding author
}

\section{Keywords \\ Media \\ effectiveness, \\ Usage pattern, \\ Psychological \\ health}

\section{Article Info}

Accepted:

18 April 2020

Available Online:

25 April 2020

\section{A B S T R A C T}

Media is the reflection of our society and is considered as the fourth pillar of democracy which makes us mindful of different social, political and financial exercises around us. Different medium of media like electronic, print and web helps making the public fully informed. Nowadays, various media like social sites, you tube channels, blogs etc. has become the voice of society and various media platforms have stimulated the thoughts of younger generation and other sections of society as influencers. So, current research was conducted with the objective to analyze role and impact of media in relation to the COVID-19 incidence \& lockdown on the psychological well-being of youth. The research will help in studying the nature of media in information dissemination and its impartiality towards people in relation to National issues and pandemic. A 21-days national lockdown has been announced to control the stage-3 of COVID-19. So, an online survey through Google tool was conducted in three different states i.e. Uttarakhand, Haryana and Rajasthan. Three universities from the respective states were selected purposively i.e. GBPUAT, CCSHAU and Rajasthan University. The results concluded that media usage has been increased during the lock down and respondents found it effective in providing the information to public. Regarding the impact of media, most of respondents felt confused and paranoid, were obeying the lock-down rules and quarantined themselves. Most of respondents were satisfied with the News channel's performances but were still unaware about the mobile app "Aarogya Setu." Apart from the safety concerns, quarantine also affected their mental health as majority of them were struggling with levels of loneliness and anxiety, insomnia, escalating nervousness and emotional exhaustion. Results further showed that majority of them converted quarantine into a productive period and dedicated time to pursue hobbies. Thus, it can be concluded that every aspect has both positive and negative sides but media has played its role effectively during lockdown and respondents followed the safety measures. Effective and efficient collaboration, coordination and implementation of media information through news channels, influencers has helped the respondents to perform productive work.

\section{Introduction}

Media and society are closely linked to each other as media is the reflection of our society and is considered as the fourth pillar of democracy which makes us mindful of different social, political and financial exercises around us. With the technological advancement, different media like electronic, print and web helps making the public fully informed and its extensive impact can be seen with the expansion of thoughts and ideas of 
people. Various media like social sites, you tube videos, blogs etc. has become the voice of society and various media platforms have stimulated the thoughts of younger generation and other sections of society as influencers.

Nowadays people are a click away from any information as it's available in the internet. With the help of different forms of media, viewers not only get updates but also create the form of understanding of the new occurring events. Television, Radio, Newspapers/E-Newspapers, Social Media, internet sources, You Tube, etc helps in disseminating the information to every nook and corner of our country. A combined Audio-Visuals aid provides a better understanding as compared to only audio, visual aid. News from all over the country is investigated and broadcasted through the mass media. Today, Television has become an important part of our life in changing the perspective through its vast messages given through its respective channels.

India is going through a lot of changes during these past months, as outbreakof Corona virus (COVID-19) in January and infection of thousands of people has created a global crisis that has a deep impact on people's everyday lives. The first case of the 2019-20 corona virus pandemic in India was reported on 30 January, 2020, originating from China and as of 5 April, 2020, the Ministry of Health and Family Welfare have confirmed a total of 3374 cases, 267 recoveries (including 1 migration) and 77 deaths in the country.

The number of infections could be substantially underestimated, as according to Global health index, 2019 India ranks at $120^{\text {th }}$ position which means that it has lowest testing rates in the world. The outbreak has been declared an epidemic in more than a dozen states and union territories.
India is second most populous country after China with 74.04 per cent literacy rate. It was media's impact that has disseminated the information in every corner of the country. India has taken the immediate action by first declaring 14-hour voluntary public curfew on 22 March, 2020 and then on 24 March there was an order of 21-days lock-down affecting the entire 1.3 billion populations. To make it successful, media has tried to play its role well and showed the news $24 \times 7$. Apart from the negative, false and provocative information/news/ WhatsApp forwards, it has shown its positive impact also.

Safety measures are put in concern to reduce the infection rate of virus by refraining from human contact and adopting social distancing. Apart from the context of physical threat, social and physical distancing also affects the psychological health of people. With the quarantine, due to less human interaction, it's difficult for some people to maintain a good physical and mental health and it could be extra harsh on people who over think and constantly needs distractions to not feel sad and lonely (The Hindu, 2020). So, it is equally important to address any kind of mental and psychosocial concerns of students during and after COVID-19 situation issue. There is need to find out the variables that are causing stress or panic in this prevailing situation. Keeping above factors in mind the present study was designed to assess the "Role and Impact of Media on Younger Generation: A Sociological Approach with respect to COVID-19 Lockdown" with the following objectives:

1. To assess the pattern of media utilization and role of media in awaking people about COVID-19 and its pandemic; and

2. To study the impact of lockdown on psychological well-being of college students. 


\section{Materials and Methods}

The present study was conducted in three Universities i.e. Gobind Ballabh Pant University of Agriculture and Technology (Pantnagar), Chodhary Charan Singh Haryana Agriculture University (Hisar) and Rajasthan University (Jaipur). These universities were selected purposively from three different states i.e. Uttarakhand, Haryana and Rajasthan respectively. Due to the lock-down (24-03-2020 to 14-04-2020), an online survey through Google tool was conducted for the collection of data regarding media and psychological impact with respect to the lockdown. Total numbers of respondents in the study were 120 and were randomly selected from the students of aforementioned universities. The statistical tool for data analysis was frequency and percentage only.

\section{Results and Discussion}

The results regarding the age of respondents showed (in figure 1) that more than half of the respondents $(57.00 \%)$ were of 22-25 years of age group. This was followed by 18-21 years of age (27.00\%) and above 25 years of age $(16.00 \%)$ respectively.

As per the first objective i.e. to assess the pattern of media and role of media in awaking people about COVID-19 and its pandemic, results were recorded and tabulated as given below. It is evident from the Table 1 that all of the respondents had smart phones. This was followed by the accessibility of television (71.67\%), Newspaper (52.50\%), Radio $(22.50 \%)$. With the availability of these media, one can easily observe the trend in news with the priorities set by various media forms. Regarding the usage of media, results showed that majority of the respondents $(97.50 \%)$ use social media. This was followed by you tube and other internet sources (85.00\%), mobile applications (80.83\%), television (67.50\%), newspaper/ e-newspaper $(49.16 \%)$ and radio $(17.50 \%)$. Around 35.83 per cent of the respondents reported that they use all of the above mentioned different communication medium as per their interest and availability.

Upon perusal of Table, it can be observed that most of the respondents (43.33\%) frequently use media daily for about 5-10 hours. This was followed by the daily frequent usage of less than 5 hours $(25.84 \%)$ and more than 10 hours $(18.33 \%)$. About 6.67 per cent of the respondents reported that they use the media sometimes only and 5.83 per cent use rarely as they spent their time doing other (productive) work and learning new things. More than half of the respondents (56.67\%) reported that their media using behavior has increased after the lockdown. While 30.83 per cent of the respondents said that there was no effect on their media using behavior and 12.5 per cent of the respondents' behavior has decreased during this period as they are engaged in other activities.

Approximately half of the respondents $(49.16 \%)$ reported that sometimes media is informative in providing the unbiased reports; while 26.67 per cent had agreed fully that it always provides unbiased reports. Further, 24.17 per cent of them believed that media, especially the News channels doesn't provide unbiased reports and tends toadd extra spice tomake everything sensational and add popularity to their respective channels.

Further, results regarding the information about COVID-19 revealed that most of the respondents $(30.00 \%)$ had first heard the news about the virus from Social Media. This was followed by you tube and other internet sources (28.33\%), television (20.83\%), newspaper/e-newspaper (15.00\%) and other media sources $(5.84 \%)$. Results further showed that most of the respondents (44.17\%) 
heard about the virus in January, 2020 while 25.83 per cent had already heard it before in December, 2019. This was followed by the spread of information dissemination in February, $2020(22.50 \%)$ and after the rise in cases in March (7.50\%).

Regarding the effectiveness of media results showed that majority of the respondents $(65.83 \%)$ felt that media was effective in disseminating authentic, timely and useful information during lock-down, while 23.34 per cent reported that it was effective sometimes only. On the other hand, 10.83 per cent respondents believed that it wasn't that much effective during the lock-down.

The information about COVID-19 has been spread from various media to the audience so that they can get aware and adopt precautions and hygiene practices. In line with this, Table 2 shows the impact of media during lockdown on lives of respondents. Most of the respondents $(44.17 \%)$ reported that they and their family members got confused, paranoid and sometimes full informed when received news from respective sources of media. This was followed by the feeling of fully informed $(32.50 \%)$, paranoid $(13.33 \%)$ and confused $(10.00 \%)$ respectively during the period.

Majority of the respondents $(97.50 \%)$ were obeying the lock-down rules and completely quarantined themselves in their respective houses while 2.50 per cent were still going out in field to help their families in farming activities. Apart from that, they were taking the safety measures to prevent themselves from the infection.

Regarding the safety measures, most of them $(43.33 \%)$ adopted the hygiene practices by washing their hands 10-20 times a day while 34.17 per cent were washing their hands for less than 10 times a day. This was followed by hand washing more than 20 times a day
(22.50\%). Results further showed that more than half of the respondents $(54.17 \%)$ only hoarded the groceries and essential items that are needed while 28.33 per cent reported that they had hoarded other items in bulk. Only 17.50 per cent respondents reported that they haven't hoard the items in bulk. Furthermore, results revealed that most of the respondents (39.17\%) did not step out of their house, and neither their house mates, while 35.83 per cent go out in a gap of 3-4 days. This was followed by going out in a week (15.83\%) and daily $(9.17 \%)$ respectively.

It is evident from the Table 2 that most of the respondents $(40.00 \%)$ were satisfied with the performances of news channels. This was followed by the response that they impart good performances sometimes (32.50\%) while 23.33 per cent weren't satisfied with their performances. Respondents reported that news channels sometimes showcased the provocative contents which are insufferable. Results further showed that majority of the respondents $(65.00 \%)$ had knowledge about the "Aarogya setu" app for COVID-19 which they received from Whatsapp, Facebook, Instagram and other social pages $(47.50 \%)$. While 35 per cent of the respondents, were unaware about the app.

Lock-down can make the people restless and they need short-term goals to lift their spirits and their engagement. As per the second objective of the study i.e. "to study the impact of lockdown on psychological well-being of college students" the results were collected and tabulated in table 3. More than half of the respondents $(52.50 \%)$ agreed to the fact that apart from the safety, social distancing and isolation, this lock-down has also affected the psychological health of people. This was followed by the results of the respondents as they strongly agreed $(20.00 \%)$, were neutral $(15.83 \%)$, disagreed $(7.50 \%)$ and strongly disagreed $(4.17 \%)$ to the fact respectively. 
Table.1 Accessibility of media in awaking respondents about COVID-19 (N=120)

\begin{tabular}{|c|c|c|}
\hline S.No. & Variables & $\mathbf{f}(\%)$ \\
\hline \multirow[t]{6}{*}{1.} & \multicolumn{2}{|l|}{ Availability of media* } \\
\hline & 1. Smartphone & $120(100)$ \\
\hline & 2. Television & $86(71.67)$ \\
\hline & 3. Newspaper & $63(52.50)$ \\
\hline & 4. Radio & $27(22.50)$ \\
\hline & 5. Other & $16(13.33)$ \\
\hline \multirow[t]{8}{*}{2.} & \multicolumn{2}{|l|}{ Usage of Media* } \\
\hline & 1. Mobile app & $97(80.83)$ \\
\hline & 2. Social media & $117(97.50)$ \\
\hline & 3. Television & $81(67.50)$ \\
\hline & 4. Newspaper/E-Newspaper & $59(49.16)$ \\
\hline & 5. Radio & $21(17.50)$ \\
\hline & 6. You tube and other internet sources & $102(85.00)$ \\
\hline & 7. All & $43(35.83)$ \\
\hline \multirow[t]{6}{*}{3.} & \multicolumn{2}{|l|}{ Frequency of Media usage } \\
\hline & 1. Daily (less than 5 hours) & $31(25.84)$ \\
\hline & 2. Daily (5-10 hours) & $52(43.33)$ \\
\hline & 3. Daily (More than 10 hours) & $22(18.33)$ \\
\hline & 4. Sometimes & $8(6.67)$ \\
\hline & 5. Rarely & $7(5.83)$ \\
\hline \multirow[t]{4}{*}{4.} & \multicolumn{2}{|l|}{ Media using behavior after Lockdown } \\
\hline & 1. Decreased & $15(12.50)$ \\
\hline & 2. Increased & $68(56.67)$ \\
\hline & 3. Not affected & $37(30.83)$ \\
\hline \multirow[t]{4}{*}{5.} & \multicolumn{2}{|l|}{ Is media informative in providing the unbiased reports } \\
\hline & 1. Always & $32(26.67)$ \\
\hline & 2. Never & $29(24.17)$ \\
\hline & 3. Sometimes & $59(49.16)$ \\
\hline \multirow[t]{6}{*}{6.} & \multicolumn{2}{|l|}{ From where have you first heard about COVID-19 } \\
\hline & 1. Television & $25(20.83)$ \\
\hline & 2. Newspaper/E-Newspaper & $18(15.00)$ \\
\hline & 3. You tube and other internet sources & $34(28.33)$ \\
\hline & 4. Social media & $36(30.00)$ \\
\hline & 5. Other & $7(5.84)$ \\
\hline \multirow[t]{5}{*}{7.} & \multicolumn{2}{|l|}{ When did you hear about COVID-19 } \\
\hline & 1. Before or In December, 2019 & $31(25.83)$ \\
\hline & 2. January, 2020 & $53(44.17)$ \\
\hline & 3. February, 2020 & $27(22.50)$ \\
\hline & 4. After the rise in cases in March & $9(7.50)$ \\
\hline \multirow[t]{4}{*}{8.} & \multicolumn{2}{|l|}{ Is Media effective during Lockdown } \\
\hline & 1. Yes & $79(65.83)$ \\
\hline & 2. No & $13(10.83)$ \\
\hline & 3. Sometimes & $28(23.34)$ \\
\hline
\end{tabular}

Note: Figures in parentheses indicate percentages

*Multiple Responses Table 
Table.2 Impact of media during Lock-down $(\mathrm{N}=120)$

\begin{tabular}{|c|c|c|}
\hline S.No. & General questions & $\mathbf{f}(\%)$ \\
\hline \multirow[t]{5}{*}{1.} & \multicolumn{2}{|c|}{ What response do you and your family have towards news from various sources } \\
\hline & 1. Confused & $12(10.00)$ \\
\hline & 2. Paranoid & $16(13.33)$ \\
\hline & 3. Fully informed & $39(32.50)$ \\
\hline & 4. All of the above in different times and situations & $53(44.17)$ \\
\hline \multirow[t]{3}{*}{2.} & \multicolumn{2}{|c|}{ Are you obeying the rules that are implemented for your safety } \\
\hline & 1. Yes & $117(97.50)$ \\
\hline & 2. No & $3(2.50)$ \\
\hline \multirow[t]{3}{*}{3.} & \multicolumn{2}{|c|}{$\begin{array}{l}\text { Did you quarantine yourself in your respective houses after the lock-down } \\
\text { announcement }\end{array}$} \\
\hline & 1. Yes & $117(97.50)$ \\
\hline & 2. No & $3(2.50)$ \\
\hline \multirow[t]{4}{*}{4.} & \multicolumn{2}{|l|}{ How many times do you wash your hands in a day } \\
\hline & 1. Less than 10 times & $41(34.17)$ \\
\hline & 2. $10-20$ times & $52(43.33)$ \\
\hline & 3. More than 20 times & $27(22.50)$ \\
\hline \multirow[t]{3}{*}{5.} & \multicolumn{2}{|l|}{ Have you hoarded the groceries and essential items } \\
\hline & 1. Yes & $34(28.33)$ \\
\hline & 2. No & $21(17.50)$ \\
\hline 6. & 3. Only that much needed & $65(54.17)$ \\
\hline \multirow[t]{5}{*}{7.} & \multicolumn{2}{|c|}{ How many times do you go out of your house during the quarantine period } \\
\hline & 1. Daily & $11(9.17)$ \\
\hline & 2. In a gap of 3-4 days & $43(35.83)$ \\
\hline & 3. In a week & $19(15.83)$ \\
\hline & 4. Haven't step out neither house mates & $47(39.17)$ \\
\hline \multirow[t]{6}{*}{8.} & \multicolumn{2}{|c|}{ Are you satisfied with the performances of news channels during this lock-down } \\
\hline & 1. Yes & $48(40.00)$ \\
\hline & 2. No & $28(23.33)$ \\
\hline & 3. Sometimes & $39(32.50)$ \\
\hline & 4. No idea & $2(1.67)$ \\
\hline & 5. Don't watch the news much & $3(2.50)$ \\
\hline \multirow[t]{9}{*}{9.} & \multicolumn{2}{|l|}{ Do you know about the "Aarogya setu" app for COVID-19 } \\
\hline & 1. Yes & $78(65.00)$ \\
\hline & 2. No & $42(35.00)$ \\
\hline & \multicolumn{2}{|l|}{ If yes, from where have you heard about it } \\
\hline & 1. News channels and TV & $36(30.00)$ \\
\hline & 2. Newspapers and Radio & $4(3.33)$ \\
\hline & 3. Whatsapp, Facebook, Instagram and other social pages & $57(47.50)$ \\
\hline & 4. You tube, Chrome and other Internet sources & $16(13.33)$ \\
\hline & 5. Family members and Relatives & $7(5.84)$ \\
\hline
\end{tabular}

Note: Figures in parentheses indicate percentages 
Table.3 Impact of Lock-down on psychological well-being of students $(\mathrm{N}=120)$

\begin{tabular}{|c|c|c|}
\hline S.No. & Variables & $\mathbf{f}(\%)$ \\
\hline \multirow[t]{6}{*}{1.} & \multicolumn{2}{|c|}{$\begin{array}{l}\text { Apart from the safety, isolation and lock down had affected the psychological health of } \\
\text { people }\end{array}$} \\
\hline & 1. Strongly agree & $24(20.00)$ \\
\hline & 2. Agree & $63(52.50)$ \\
\hline & 3. Neutral & $19(15.83)$ \\
\hline & 4. Disagree & $9(7.50)$ \\
\hline & 5. Strongly Disagree & $5(4.17)$ \\
\hline \multirow[t]{11}{*}{2.} & \multicolumn{2}{|c|}{ Psychological vulnerability of people during Quarantine* } \\
\hline & 1. No effect on mental health & $11(9.17)$ \\
\hline & 2. Struggling with levels of loneliness & $76(63.33)$ \\
\hline & 3. Anxiety & $52(43.33)$ \\
\hline & 4. Pre-existing conditions of depression & $7(5.83)$ \\
\hline & 5. Escalating nervousness & $29(24.17)$ \\
\hline & 6. Obsessive compulsive disorder & $13(10.83)$ \\
\hline & 7. Confusion & $21(17.50)$ \\
\hline & 8. Anger & $28(23.33)$ \\
\hline & 9. Insomnia & $47(39.17)$ \\
\hline & 10. Emotional exhaustion & $42(35.00)$ \\
\hline \multirow[t]{10}{*}{3.} & \multicolumn{2}{|l|}{ Major activities performed during quarantine* } \\
\hline & 1. Doing no physical activity & $27(22.50)$ \\
\hline & 2. Cooking & $45(37.50)$ \\
\hline & 3. Cleaning & $39(32.50)$ \\
\hline & 4. Gardening & $22(18.33)$ \\
\hline & 5. Eat-sleep-repeat cycle & $61(50.83)$ \\
\hline & 6. Binge-watching & $52(43.33)$ \\
\hline & 7. Reading new books & $26(21.66)$ \\
\hline & 8. Listening to music & $57(47.50)$ \\
\hline & 9. Learning new things & $23(19.17)$ \\
\hline
\end{tabular}

Note: Figures in parentheses indicate percentages

*Multiple Responses Table

\section{Age (In years)}

-18-21 $\square 22-25 \square$ Above 25

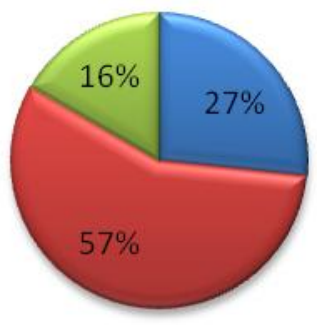

Figure.1 Age (In years) of respondents 
Regarding the psychological vulnerability of the people during quarantine, it is evident from the Table 3 that majority of them $(63.33 \%)$ struggled with levels of loneliness while 43.33 per cent suffered from anxiety. This was followed by insomnia $(39.17 \%)$, emotional exhaustion $(35.00 \%)$, escalating nervousness $(24.17 \%)$ and anger $(23.33 \%)$ respectively in the minds of respondents. Results further showed that some respondents were confused $(17.50 \%)$ and also suffer from Obsessive compulsive disorder (10.83\%).

Apart from these vulnerabilityies, 9.17 per cent of them reported that lock-down has no impact on their mental health. As per the major activities performed during quarantine, it is evident from Table 3 that half of the respondents $(50.83 \%)$ are only repeating the eat-sleep cycle while 47.50 per cent spent their time listening to music. This was followed by binge-watching TV/web series (43.33\%), cooking (37.50\%), cleaning (32.50\%), doing no physical activity (22.50\%), reading new books (21.66\%), learning new things $(19.17 \%)$ and gardening $(18.33 \%)$ respectively.

The results concluded that usage of media has increased during the lock down and people found various forms of media effective in providing the information to public. Regarding the impact of media, most of them felt confused and paranoid, were obeying the lock-down rules and did quarantine themselves. Most of them were satisfied with the News channel performances but were still unaware about the mobile app "Aarogya Setu." Apart from the safety concerns, quarantine also affected their mental health as majority of them were struggling with levels of loneliness and anxiety, insomnia, escalating nervousness and emotional exhaustion. Majority of the people are trying to make the lock-down period productive by dedicating time to hobbies or learning new things. Media influencers are also playing effective roles in influencing the public and young minds by practicing physical exercises, doing productive work, enhancing their skills, etc. Media can play a very effective role in disseminating timely, authentic and impactful information during these testing times, but all sorts of media should refrain from sensationalism, exaggerations and TRP/Popularity perusal. Ethical news and sincere approach would be most appreciated by the public, as these are not regular or typical times. No other source apart from electronic and print media can maintain solidarity and prevent chaos in these times.

\section{References}

Nity. and Singh, G. (2017). Role and impact of media on society: a sociological approach with respect to demonetization. International Journal of Research in Humanities, Arts and Literature. 5(10).

www.frontiersin.org/researchtopics/13638/coronavirus-diseasecovid-19-the-impact-and-role-ofmass-media-during-the-pandemic on 6 April 2020 at 9.47 AM

www.google.com/amp/s/www.orissapost.com /global-health-index-ranked-120th/ on 5 April 2020 at 9.00 PM

www.google.com/amp/s/www.thehindu.com/ society/isolation-and-mental-healththe-psychological-impact-oflockdown/article31237956.ece/amp/ on 5 April 2020 at 7.45 PM

www.mohfw.gov.in. on 5 April 2020 at 5.40 PM

www.wikipedia.org/wiki/2020_coronavirus_p andemic_in_India on 6 April 2020 at $10.10 \mathrm{AM}$ 
How to cite this article:

Shatakshi Semwal and Ragini Ranawat. 2020. Role and Impact of Media on Younger Generation: A Sociological Approach with Respect to Covid-19 Lockdown. Int.J.Curr.Microbiol.App.Sci. 9(04): 2425-2433. doi: https://doi.org/10.20546/ijcmas.2020.904.291 